\title{
GENDER RELATIONS AND SUBJECTIVE FAMILY WELL-BEING AMONG FARMER FAMILIES: A COMPARATIVE STUDY BETWEEN UPLANDS AND LOWLANDS AREAS IN WEST JAVA PROVINCE, INDONESIA
}

\author{
Herien Puspitawati ${ }^{1 *}$, Paula E. Faulkner ${ }^{2}$ Ma'mun Sarma $^{3}$, \\ Tin Herawati ${ }^{4}$ \\ ${ }^{1,4}$ Department of Family and Consumer Sciences, Faculty of Human \\ Ecology, Bogor Agricultural University \\ ${ }^{2}$ North Carolina Agricultural \& Technical State University \\ ${ }^{3}$ Department of Management, Faculty of Economics and Management - \\ Bogor Agricultural University.
}

*Correspondence Author: herien_puspitawati@email.com

\begin{abstract}
The objectives of this study are described as follows: (1) To examine the conditions of social, economic and demographic characteristics of poor farmer families who live at uplands and lowlands areas, (2) to describe the social-cultural and agroecosystem conditions of poor farmer families who live at uplands and lowlands areas, (3) To explain type of gender relations of poor farmer families who live at uplands and lowlands areas, and (4) to analyze factors that influenced subjective family well-being of poor farmer families who live at uplands and lowlands areas. The chosen research sites were Nanggung Sub-district, Bogor District as an upland area, and West Teluk Jambe Sub-district, Karawang District, West Java Province as a lowland area. The total of 189 farmer families was used for this study $(\mathrm{n}=90$ in uplands district areas, and $\mathrm{n}=$ 99 in lowlands district areas). It was found that the conditions of social-cultural and agroecosystem differ between upland and lowland areas. In general, both upland and lowland areas gender roles on farming activities, in terms of access and control to agricultural resources, were dominated by men. Family well-being was directly influenced by higher education of husband and wife, indirectly influenced by less economic pressure of the family, directly influenced by higher gender relations between husband and wife, and directly influenced by less or higher external support. Thus, wealthy farmer families were the family that had educated husband and wife, less economic pressures, equal gender relations and partnerships, and less or more receive external supports. It is recommended that the next study should add variables of family coping strategies related to family economic pressure and gender roles between husband and wife.
\end{abstract}

Keywords: Gender Relations, Subjective Family Well-Being 


\section{Introduction}

Indonesia is an archipelago country located in South Asia and lies on the ring of fire between Asia and Australia, and between the Pacific and Indian Oceans. Indonesia has more than 17,500 islands. Over the years, the country has experienced a global economic crisis since 1997. This crisis has affected many aspects of life, socially and economically. Another crisis faced in Indonesia including poverty and natural disasters (include volcanic issue). Poverty is a multidimensional issue that has become a major problem for Indonesia, affecting the transitions of the national environment of social, economic, and politics. As of 2004, poverty alleviation programs have not been accomplished as whole, and the condition even worsened due to the increasing price of fuel/gasoline in 2005. Moreover, poverty alleviation programs have not thoroughly accommodated in rural communities' local agroecological knowledge, that could lead to agricultural potential. In fact, Indonesia has the potential to advance in the area of agricultural production which could help solve the poverty crisis through strengthened food security and food sovereignty. About 45 percent of Indonesian workers $(47,894,000)$ were engaged in agriculture in 2008, which accounted for only 15.3 percent of GDP in 2009. Indonesian Women in rural area have also participated in the agricultural sector $(61 \%)$. Moreover, women contributed to nearly 75 percent of the farm work in rice production. Nearly 60 percent of the country's cultivated land is found at Java Island which has the highest poverty rate.

The impacts of poverty on community are multidimensional, i.e. social, economic, psycho-social and mental. This supports the reason why poverty alleviation programs should include all elements of the community including attributes, values, customs, and other potentials. Empowerments should start by the shaping of individuals' mindsets, the habits of families, and the norms of the community. One study on gender relations in farmer families by Trikoesoemaningtyas (2009) stated that there had been gender gaps in family activities and family decision making. Gender roles in domestic activities have been dominated by women, while gender roles in farming activities have been dominated by men. However, the existence of gender relations between men and women was low to moderate level in farming production and was low in marketing agricultural commodities. Another study stated that gender relations in domestic, productive and social activities become one strategy to enable economic function for the family to increase their family well-being. The gender relations showed by the decision made between husband and wife in family activities have been able to alleviate family from poverty and could increase the family well-being (Puspitawati, 2009a; Puspitawati, 2009b).

One of the major national problems in Indonesia is shown by the high number of poor population as a result of the global economic crisis. The high poverty level has increased families vulnerability and their incapability to fulfill basic needs such as foods, clothes, houses, and education. This incapability of family economic function reflected 
the incapability of family organization among family members including gender relations. The Central Bureau of Statistics or BPS (2007) states that the number of people in poverty had decreased between 1976 - 1996 both in absolute numbers and percentage, it started to increase during the national economic crisis between 1997 1999 and decreased again in 2000 (Bappenas \& ADB, 2007). In March 2008, the total of people in poverty was 34.96 million people (15.42\%) which decreased to about 2.21 million people compared to the previous year (BPS 2008). Considering high cases of poverty, Indonesia is unlikely to achieve the Millenium Development Goal targets in 2015 which includes reducing the poverty rate as much as 8.3 percent in 2009 , as mandated by international and national constitutions.

Another problem is related to the gender gap at the family level in rural areas, which are shown by the dominance of men in the decision making of family activities. This condition has been continued for generations as typical of a patriarchy system that is very common among rural agricultural communities in Indonesia. Women are marginalized and have lower bargaining position compare to men, especially in agricultural activities. This resulted in unequal gender relations, as there is a low partnership between men and women within farmer families. To alleviate poverty with its multidimensional aspects, the need to address the factors that influence family wellbeing is imperative. Based on the problems of poverty and gender in decision making in the family, several research questions have been proposed as follows: 1) How are the brief characteristics of social, economic and demographic of farmer families?; 2) How are the characteristics of social-cultural, agroecosystem and gender relations within farmer families?; 3) What factors affecting family well-being?

Most research studies addressed the need for strategies to alleviate poverty by examining the livelihood of the poor family. However, there are only a few studies address the gender relations in the family level. That is why there is a need to examine gender and family issues in relation to poverty and well-being to understand gender roles among farmer families and 'who does what.' Deacon and Firebaugh (1988) stated that families are influenced by their environments such as social environment and physical environment. Gender refers to the economic, social, political, and cultural attributes and opportunities associated with being female and male that vary among cultures and changes over time (USAID, 2006). One of the important empowerment strategies by considering gender relations at family and community levels is to increase both individual and family capacities to cope with the impacts of poverty. Gender and family empowerment could be viewed as an "entry point" in poverty alleviation strategies through the strengthening of gender relations and partnerships to manage scarce family resources equally and fairly. This study was designed to focus on gender relation in family level well-being and its effect on family subjective well-being. The study benefits academics, communities, and the Indonesian government which relates to the developments of gender relation in a family to increase family well-being.

The focus of this study is to examine the family well-being and gender relations within the family. Based on the U.S. Bureau of the Census, a family consists of individuals who live in the same household (Newman \& Grauerholz 2002). Thus, the wealthy families mean the families who are able to fulfill the proper physical and mental 
needs and able to manage the harmonious relations among family members and their environment (Landis, 1989). One of the grand family theories used in this study is Structural Functional Theory developed by Spencer and Durkheim describe on structure (rules of social relations) and functions in the community (Skidmore 1979; Spencer dan Inkeles 1982; Turner 1986; Schwartz dan Scott 1994; Macionis 1995; Winton 1995). The structural functionalists view the social system as the equilibrium system, harmonious and sustain. Gender is described by USAID (2006) as the social definitions of what it means to be female or male associated with the economic, social, political, and cultural attributes and opportunities. This concept of gender varies between cultures and changes over time. In order to examine gender equality in household and community levels, gender analysis is essential to be applied. Miller and Razavi (1998) described that gender analysis is a type of socio-economic analysis and as a tool to identifies the types of gender differences and inequalities - such as how men and women have different access to and control over resources, carry out different social roles, and face different constraints and receive different benefits. The gender analysis applied in household and community levels includes the Moser Gender Planning Framework and the Harvard Analytical Framework. Caroline Moser develops one of the most popularly used frameworks called Moser's Gender Planning Framework (ILO, 1998). The analysis relates to gender roles, gender needs, and policy approaches to gender and developing planning. One of the strengths from this analysis is its concerned on distinguishes between types of gender needs of women's daily lives but maintain existing gender relations (practical gender needs), and the potentially transform existing gender subordination (strategic gender needs).

Another gender analysis was developed by researchers at the Harvard Institute of International Development (HIID) in collaboration with USAID's Office of Women in Development called the Harvard Analytical Framework or sometimes called the GFA (Gender Framework Analysis) (originally outlined in Overholt et al., 1984). This one of the earliest gender analysis comprised of interrelated components for collecting data at the community and household levels including activity profile which answers the question of "who does what?", Access and control profile which identifies the resources used to carry out the work, and access to control over their use, by gender. Based on this analysis, data is collected on men's and women's activities which are identified as either "reproductive" or "productive' types.

Study on women and agriculture raised the questions of who counts, who is counted, what is counted, and how things are counted. Study on Australian women in agriculture highlighted the way in which women were simply not seen as farmers even at the beginning of the 1990s. Women typically enter farming through marriage as a daughter-in-law together with the patrilineal inheritance systems. It means that women are far less likely than men to access agricultural resources such as own farming land (Pini, 2004). Moreover, the study on the gender role of farmer families examines the on-farm substantial work role which is traditionally defined as masculine and viewed as the domain of men. However, the study resulted that women have crossed the traditional gender division of labor that involved in on-farm physical labor and the use of large machinery (Pini, 2005). 
It is stated that the role of women in productive activities is poorly measured in the social science literature. Evidence indicates that women's work is underreported in official data, censuses, and labor force surveys. Then, it is likely that unreported work makes a substantial contribution to family welfare, especially domestic work that contributes to family well-being (Langsten, R. \& Salen, R. 2008). The purpose of this study was to examine the conditions of poor farmer families concerning social and economic characteristics, gender relations, and subjective family well-being between farmer families who live at uplands and lowlands areas in West Java Province, Indonesia. The objectives of this study are described as follows: 1) To examine the conditions of social, economic and demographic characteristics of poor farmer families who live at uplands and lowlands areas; 2) To describe the social-cultural and agroecosystem conditions of poor farmer families who live at uplands and lowlands areas; 3) To explain the type of gender relations are demonstrated by poor farmer families who live at uplands and lowlands areas; 4) To analyze factors influenced subjective family well-being of poor farmer families who live at uplands and lowlands areas.

\section{Method}

This descriptive study examined the conditions of the family concerning social and economic characteristics, gender relations, and subjective family well-being of poor farmer families who live at uplands and lowlands areas in Indonesia. This research was funded by the Ministry of National Education-Republic of Indonesia under the National Priority Research Grants Number: 160/SP2H/PP/DP2M/V/2009.

The target population for the study included poor farmer families. The sampling unit was poor farmer families who owned small pieces of land. The combination of Central Bureau of Statistics of the Republic Indonesia (2009) criteria (poverty line of West Java Province-IDR 183,068 monthly per capita) and the locally based criteria who owned land less than 0.2 hectares were used to identify the poor farmer families. The respondents were married female farmers with the assumption that the wives would know more about gender roles, productive, reproductive, or social activities rather than their husband. Two hundred farmers' families were asked to participate in the study (100 farmer families from each area). A purposive technique was used for sampling due to the farmers' willingness to participate. The lists of poor farmer families were taken from the village office administrations to examine the land ownership areas of the farmers. In order to confirm on the status of the poor farmer families, the information from the village official and the dusun's (sub-village area) leader was gathered so that the sample valid and suitable with the criteria. Finally, 189 farmer families were used for this study ( $n=90$ in uplands district areas, and $n=99$ in lowlands district areas).

Researchers used a mixed mode approach to conduct the study. A survey instrument for the household survey was used to interview the wife of the farmer. Moreover, the in-depth interview with village leaders and non-formal leaders were also applied, mixed with the actual field observations. The chosen research sites were Nanggung Sub-district, Bogor District as an upland area, and West Teluk Jambe Sub- 
district, Karawang District, West Java Province as a lowland area. This study was conducted with the following limitations: 1) The poor farmer families were selected from one village at uplands areas (Hambaro and Sukaluyu Villages, Nanggung SubDistrict, Bogor District) and one village at lowlands areas (Karangligar Village, West Teluk Jambe Sub-District, Karawang District). The village represents one of the poor villages, the sub-district represents one of the poor sub-districts, and district represents one of the lowlands or upland poor areas; 3) The respondents were limited to women to represent their family. There was a potential for bias with responses based on their point of view; 3) The population of this study was limited to poor farmer families who had land less or equal to 0.2 hectares, and excluded landless poor farmers; 4) The Likert scale applied in this study was 1 to 3 considering the low education, knowledge, and experiences of the poor farmer families. The following assumptions were made while conducting this study: 1)Participant responses were honest and accurate; 2)The enumerators questioned and instructed the instruments homogenously because the enumerators trained in a week before the survey was conducted unclear.

A survey instrument was developed to collect the data required. The instrument included items modified from Moser (1993) that investigated and measured 'triple gender roles' of productive, reproductive and community activities. Once the survey instrument was constructed for this study, the instrument was reviewed for content validity by a national committee/jury for grants competition from the Directorate General of Higher Education, Ministry of National Education- Republic of Indonesia. The committee consisted of national experts in social sciences and faculty members from respected universities in Indonesia. The paper was also presented at the National Reviewer Committee from the Directorate General of Higher Education, the Ministry of National Education- the Republic of Indonesia at Jakarta, December 8, 2009, and at Bogor. Section one of the instrument focused on the characteristics of farmer families, including the age (by years) and the education of all family members (by years), the number of family members (by numbers), the average of monthly income (IDR per month), the average of monthly expenditures (IDR per month), and the home ecology (description of the house). Section two of the instrument focused on respondents' perceived of family economic sufficiency modified from Conger survey instrument (1994). Seven items assessed to the extent to which family economic pressures or sufficiencies were perceived by. The items included having not enough money to buy clothes, school bills, foods, electricity, and disagreements about money. The seven items were measured on a 3 -point Likert-type scale ranging from $1=$ seldom, $2=$ sometimes, $3=$ very often.

Section three of the instrument focused on the respondent's perspectives of gender relations in family decision making in family activities (modified from Moser, 1993; Deacon \& Firebaugh, 1988, and Oxfarm, 1994). Sixty items are used to asses the extent to which gender relations in decision making and the implementation in family activities. The items included in decision making and implementation on domestic chores (such as decisions on food expenses, the decisions to reduce food needs, deciding to eat out), and management of family resources (such as making family financial plans, evaluating behaviors of family members, controlling family members in spending 
money, managing family expenditures). A 3-point Likert-type scale ranging from $1=$ husband/wife only, $2=$ husband dominant/wife dominant, and $3=$ husband and wife equally.

Section four of the instrument focused on the perceived gender relations in decision making in farming activities (modified from Moser, 1993, and Oxfarm, 1994). Sixteen items assessed the extent to which gender relations in decision making and the implementation in farming activities occurred. The items included decision making and implementation on farming activities such as making farms' financial plans, predict the farming budget, record farming expenditures, manage farming finances, implement the expenditures of farming budget as planned, evaluate the farming management, plan the plants for farming commodities, and manage the home yards by planting food crops or raising animal livestock. The 16 items were measured on a 3-point Likert-type scale ranging from $1=$ husband/wife only, $2=$ husband dominant/wife dominant, $3=$ husband and wife equally.

Section five of the instrument focused on the perceived of family subjective well-being (modified from Toronto-Ontario Social Development Council, 1997). Twenty items assessed the subjective well-being perceived by family. The items included material satisfaction (such as family financial conditions, food, house, material goods/assets, and physical health) and non material satisfaction (such as spiritual/ mental well-being, relationships with parents/parents in law/relatives/neighbors, and the feeling towards the home's cleanliness, children's education, children's behaviors, the communication with her husband, and the husband's contributions to household chores). The 20 items were measured on a 3-point Likert-type scale ranging from 1= unsatisfied, $2=$ sometimes satisfied, $3=$ very satisfied.

Section six of the instrument focused on respondents perception of external supports. The items included the extended family supports and neighbors support either material or non-material. The 8 items were measured on a 3-point Likert-type scale ranging from $1=$ seldom, $2=$ sometimes, $3=$ very often. The three Likert scales included on the instrument were checked for reliability using survey responses. Cronbach's alpha coefficients indicated that most of the scales were reliable (see Table 1).

Table 1 Reliability (Cronbach Alfa $(\alpha)$ ) for the Three Scales on the Survey Instruments

\begin{tabular}{|c|c|c|c|c|}
\hline \multirow{2}{*}{ Dependent Variable } & \multirow{2}{*}{ \# of Items } & \multicolumn{2}{|c|}{ Alpha $(\alpha)$} & \multirow[b]{2}{*}{ Total } \\
\hline & & Upland & Lowland & \\
\hline \multirow{3}{*}{$\begin{array}{l}\text { The perceived of family economic } \\
\text { pressures/sufficiency } \\
\text { The perceived gender relations in } \\
\text { decision making in family activities } \\
\text { The perceived gender relations in } \\
\text { decision making in farming activities }\end{array}$} & 7 & 83 & .83 & .83 \\
\hline & 60 & 93 & .88 & .91 \\
\hline & 16 & 94 & .93 & .94 \\
\hline The subjective family well-being & 22 & 89 & .84 & .87 \\
\hline
\end{tabular}




\begin{tabular}{lrrrr}
\hline \multirow{2}{*}{ Dependent Variable } & \multirow{2}{*}{ \# of Items } & \multicolumn{3}{c}{ Alpha $(\alpha)$} \\
& & Upland & Lowland & Total \\
\hline The external support & \multirow{2}{*}{$\begin{array}{c}* \\
5\end{array}$} & 55 & .70 & .63 \\
\hline
\end{tabular}

The study was conducted from June 2009 to November 2009. Data were collected July 1, 2009, to October 2, 2009. Several steps were applied to the process of data collections. The first step was the request for permission to begin the procedures from the provincial, district, sub-district, and to village central governments (July 1-6, 2009). The permission included the proof of ethical clearance that was signed by the Office of Research and Community Services from Bogor Agricultural University. The second step was visiting the village that was accompanied by the sub-district official with the purpose of socialization of the research purpose and procedures (July 7-8). The third step was a one-week training of the enumerators (consisted of 6 female undergraduate senior students/new graduate students from bachelor degree) with 2 days (July 9-10) in class training held at Bogor Agricultural University, and then continued by 3 days training (July 13-15) at research locations. Based on these, the questionnaires were revised again in terms of the contents and the language (July 16-17). The fourth step was preparing the codebook (the variable's coded for entering the data into a computer by using an SPSS format) (July 20-21). The fifth step was conducting a survey of the households (July 22 to October 2 or in 73 days) (see Table 2).

Table 2. Steps, Time and Descriptions of Data Collection $(n=189)$

\begin{tabular}{|c|c|c|}
\hline Activity & Time & Descriptions \\
\hline $\begin{array}{l}\text { Step 1: Requesting permission } \\
\text { from the provincial, district, } \\
\text { sub-district, and to the village } \\
\text { administrative government }\end{array}$ & July 1-6 & $\begin{array}{l}\text { Requesting permissions procedures } \\
\text { The permission including the proof of } \\
\text { ethical clearance that has been signed } \\
\text { from the Office of Research and } \\
\text { Community Services from Bogor } \\
\text { Agricultural University }\end{array}$ \\
\hline Step 2: Entering the village & July 7-8 & $\begin{array}{l}\text { The procedures entering the village that } \\
\text { was accompanied by the sub-district } \\
\text { official with the purpose of socialization } \\
\text { of the research purpose and procedures }\end{array}$ \\
\hline $\begin{array}{l}\text { Step 3: Training of the } \\
\text { enumerators }\end{array}$ & $\begin{array}{l}\text { July } 9- \\
10 ; \text { July } \\
13-15 ; \\
\text { July 16- } \\
17\end{array}$ & $\begin{array}{l}\text { One-week training of the enumerators } \\
\text { (consisted of } 6 \text { female undergraduate } \\
\text { senior students/fresh graduate from } \\
\text { bachelor degree) with } 2 \text { days (July 9-10) } \\
\text { in class training that was held at Bogor } \\
\text { Agricultural University, and then } \\
\text { continued by } 3 \text { days training (July 13-15) } \\
\text { at research locations. } \\
\text { Based on these training, the }\end{array}$ \\
\hline
\end{tabular}




\begin{tabular}{lll}
\hline Activity & Time & $\begin{array}{l}\text { Descriptions } \\
\text { questionnaires were revised again in } \\
\text { terms of the contents and the language } \\
\text { (July 16-17). }\end{array}$ \\
\hline Step 4: Preparing Code Book & $\begin{array}{l}\text { July 20- } \\
21\end{array}$ & $\begin{array}{l}\text { Preparing the codebook (the variable's } \\
\text { coded for entering the data into a } \\
\text { computer by using an SPSS format) }\end{array}$ \\
\hline Step 5: Conducting survey & $\begin{array}{l}\text { July 22 } \\
\text { Conducting a survey of the households } \\
\text { October } \\
2 \text { or in 73 } \\
\text { days }\end{array}$ \\
\hline
\end{tabular}

The study included qualitative and quantitative data as well as primary and secondary. Primary data gathered from the surveys which include social, economic, and demographic characteristics of the farmer families, gender relations in survival strategies; and subjective family well-being. Secondary data was gathered from village administration offices, including empowerment programs, village potential data, and population data. The observation data included the agro-ecology of the area and also the conditions of the community.

The data were analyzed using the Statistical Package for the Social Sciences (SPSS, version 15.0) by applying the t-difference test between uplands and lowlands areas. The Structural Equation Modeling (SEM) technique (LISREL version 8.80 Edition Student (July 2006)) was used to examine the direct and indirect effect in influencing subjective family well-being. Finally, descriptive analyses were used to describe the conditions of agroecology and the conditions of community between uplands and lowlands areas. The scale of measurement used for all of the analysis was:

1. Using a 3 Likert scale of-- $1=$ seldom, $2=$ sometimes, $3=$ very often - to assess the perceived of family economic sufficiency and the perceived of external supports. The individual scale then will be sum to measure the total score of these variables.

2. Using a Likert scale of $1=$ husband/wife only, $2=$ husband dominant/ wife dominant, $3=$ husband and wife equally-- to assess the perceived of gender relations in the decision making of family and farming activities. The individual scale then will be sum to measure the total score of the variable.

3. Using a Likert scale of $--1=$ unhappy/unsatisfied, $2=$ sometimes happy/satisfied, $3=$ very happy/satisfied; or $1=$ unsatisfied, $2=$ sometimes satisfied, $3=$ very satisfied--to assess the perceived of family subjective well-being. The individual scale then will be sum to measure the total score of the variable.

\section{Findings}




\section{The social, economic and demographic characteristics of farmer families}

Based on the household surveys, it was discovered that the largest proportion of both farmer families in upland and lowland areas had not graduated from elementary school. The average amount of wives' education was 4.4 years, and the average number of family members was 6 persons.

Regarding the conditions of the house, the walls of all the farmers' houses were made of bricks, and all of the roofs were made of roof tile. Most of the houses' floors were made of concrete/ceramics/cement. The clean water source of the community came from the springs surrounding the village. The villagers used the spring water for daily purposes, such as taking baths, drinking, washing dishes, washing clothes, caring for the animals, and cleaning the house. All of the male and female respondents had a washing room in their house with a closet and water storage.

More than half of the farmers had small livestock animals, such as chickens, ducks, goats, and even big livestock animals such as cows. It was discovered that more than three-fourths of farmers had average monthly incomes less than IDR 1000000 in both areas. The average monthly family income was IDR 778242.50 in upland areas and IDR 1587434 in low land areas. From the two areas, the average income per capita was IDR 133778,82 . The average monthly family expenditure was IDR 936087.44 in upland areas and IDR 1721102.30 in lowland areas. We can see here that the farmers' budget deficit in both areas. Results showed that more than half of farmers had an average debt of IDR 237868.85 in upland areas and IDR 1347075 in lowland areas. For the family expenditures, the five largest areas of families' expenditures in upland areas were paying for cigarettes (IDR 108 930.33), children's education (IDR 105 640.75), rice (IDR 85 296.67), electricity (IDR 71 525.08), and dishes such as fish for dinner (IDR 70 600.83). The five largest areas of families' expenditures in lowland areas were paying for children's education (IDR 213 346.67), others - such as social gathering (IDR 177 773.33), cigarettes (IDR 121 837.92), rice (IDR 119 508.33) and dishes such as chicken for family dinners (IDR 103 905.42).

In general, the economic conditions of farmers in lowland areas were better than

in upland areas. This finding was also supported by the reports of three-fourths of farmers in lowland areas that both husband and wife had never argued about the family finances. Half of the farmers in lowland areas reported the sufficiency of their money to buy clothes, children's education, food, and agricultural inputs.

\section{The social-cultural and agroecosystem characteristics}

The conditions of social-cultural and agroecosystem differ between upland and lowland areas. The figure below presents the variety of such conditions summarized from the survey, field observations (a transect method), secondary data and in-depth interview from local leaders. Results show that the conditions of upland areas of Bogor District are hilly, have potential of food, non-active farmer's groups -especially women's involvement, the close partnership of husband and wife in farming system, access and control of women to local government programs were still low, the programs have been implemented since 2009, and the existence of socio-cultural constraint such as 
conservative norms typical of traditional agriculture communities. On the other hand, the conditions of lowland areas of Karawang District are flat, close to sea/beach, villages separated by wide paddy fields, rice that has potential to become national stocks, active farmer's groups, low women involvement, moderately high partnerships between husband and wife, women has low access and control to local government programs, few women involved in farming. Since the poverty alleviation programs had been implemented in 2008, the norms are more moderate for changes in gender relations as typical of semi-modern agriculture communities. 
- Topography and infrastructure: Upland areas, hilly; asphalt roads-provincial roads; congested traffic; the villages are close to each other.

- Agroecosystem: a potential for food crops—vegetables, fruits; dry-fields; a wide agricultural land area.

- Local economic institutions: non-active farmer's groups; low women involvement; non-active local social-cultural institutions.

- Gender roles in farming: Partnership of husband and wife is high.

- Access and control of women to local government programs and farming resources were low.

- Women's involvement in farming: Many women involved in farming activities, both wet and dry lands because the narrowness of land areas and the purpose of farming was for subsistence.

- Roles in family activities: Partnership of husband and wife is moderately high; family often apply survival strategies.

- The subjective family well-being: High.

- Poverty alleviation programs: The programs have been implemented since 2009.

- Social-cultural constraints: The conservative norms limit women and men to seek a lot of job opportunities outside the village; static and monotone as typical of traditional agriculture communities.

Social-cultural and agroecosystem conditions of upland areas (Bogor District)
- Topography and infrastructures: Lowland areas, flat, close to sea/beach; asphalt roads-national roads, close to toll-road; very congested traffic; the villages are separated by very wide paddy fields.

- Agroecosystem: a potential of rice to become a national rice stock area; the potential of mango; technical irrigation channels; very wide agricultural lands.

- Local economic institutions: Active farmer's groups; low women involvement; non-active local social-cultural institutions.

- Gender roles in farming: Partnership of husband and wife is moderately high.

- Access and control of women to local government programs were low, and to farming, resources were quite high.

- Women's involvement in farming: Few women involved in farming, both wet and dry lands because the purpose of farming was commercial.

- Roles in family activities: Partnership of husband and wife is high; family often applies survival strategies.

- The subjective family well-being: Moderately high.

- Poverty alleviation programs: The programs have been implemented since 2008.

- Constraints of social-cultural: The norms are more moderate for changes in gender relations; dynamic communities as typical of semi-modern agriculture communities.

Social-cultural and agroecosystem conditions of lowland areas (Karawang District)

Summarized from the survey, field observations (a transect method), secondary data and in-depth interview from local leaders. Figure 1. The Variety of social-cultural and agroecosystem conditions of upland and lowland areas at West Java, Indonesia. 


\section{Gender relations within the family}

Results from the survey, field observations (a transect method), primary data and in-depth interview from local leaders showed that in general in both upland and lowland areas, gender roles in farming activities in terms of access and control to agricultural resources were dominated by men. However, men and women benefited from farming activities. The gender relations between husband and wife in farming systems both in upland areas and in lowland areas were almost the same (the mean score were 30.22 and 32.09 respectively $(\mathrm{p}=0.161))$. Relating to the decision making and implementation of farming activities, the largest proportion of farmer families showed a moderate relation between husband and wife in both areas. However, there was an interesting characteristic of women involved in farming activities between upland and lowland areas. More women in upland areas were involved in farming activities because of the narrowness of land areas and the purpose of farming which is subsistence. While only a few women in lowland areas were involved in farming activities both wet and dry lands because of the wide of land areas and the purpose of farming was commercial. The gender relations and partnership in domestic spheres showed that in general there had been high relations between husband and wife in planning and implementing family activities in both areas. It is interesting to see that the gender relations between husband and wife domestic activities in upland areas was significantly lower than that in lowland areas (the mean score were 129.54 and 138.06 respectively $\left(\mathrm{p}=0.022^{*}\right)$ ).

Moreover, there were differentiated gender roles between husband and wife in both areas. Women typically dominated decision making on food expenditures and other expenditures such as kitchen wares and supplies. However, the expenditures related to children's education and health maintenance were made by both husband and wife. Activities that related to work outside the home were only decided by men.

Results of family well-being showed that the quality of family subjective wellbeing was in moderate levels in upland and lowland. The well-being in upland and lowland areas were almost the same (the mean score were 50.18 and 48.28 respectively $(\mathrm{p}=0.111))$. The subjective well-being was shown by the satisfaction of the family in conditions of food, house, and its microenvironment, assets, spiritual, psycho-social, physical health, communication among family members, children's education, and family finances. Figure 2 shows gender relations within the family between uplands and lowlands at West Java, Indonesia.

\section{Factors affecting family well-being: A Structural Equation Modeling (SEM) analysis.}

Figure 3 showed that the value of Chi-Square, GFI (Goodness of Fit Index), CFI (Comparative of Fit Index) and RMSEA (Root Mean Square Error Approaximate) were $29.84(\mathrm{p}=0.00), 0.96,0,92$ and 0.09 respectively for the total samples $(\mathrm{n}=189) ; 33.08$ $(\mathrm{p}=0.00), 0.91,0.75$, and 0.14 respectively for samples at upland areas $(n=90)$; and $20.15(\mathrm{p}=0.06), 0.95,0.94$, and 0.08 respectively for samples at lowland areas $(\mathrm{n}=99)$. 
Based on these results, it can be said that the models fit the data (based on the criteria of Bollen,1989).

Results at Table 3 described that the latent variable of gender relations between husband and wife - which was indicated by gender relations on decision making, in family and farming activities among farmer families in lowland areas were influenced directly by: (1) The economic conditions of the family, such as the perceived of sufficiency of family economics $\left(\beta=-0.16^{*}\right.$ for total samples, and $\beta=-0.36^{*}$ for samples at lowlands); and (2) external supports from extended family and community ( $\beta$ $=0.31^{*}$ for samples at lowlands). There has not been enough support to prove the factors influenced gender relations at upland areas.

The latent variable of family well-being - which was indicated by family subjective well-being- was influenced: (1) Directly by the social conditions of family, such as husband and wife's education and the perceptions of gender roles-- for total samples $\left(\beta=0.12^{*}\right)$; (2) Indirectly by the economic conditions of family, such as the perceived of family economics' sufficiency_at lowland areas $(\beta=-0.13 *)$; (3) Directly by gender relations between husband and wife, such as in decision making in family and farming activities — at total samples $\left(\beta=0.51^{*}\right)$, samples at upland areas $\left(\beta=0.59^{*}\right)$ and samples at lowland areas $\left(\beta=0.37^{*}\right)$, and (4) Directly by the external supports from extended family and community at samples' upland areas $\left(\beta=-0.19^{*}\right)$ and indirectly in lowland areas $(\beta=0.08 *)$.

Based on the results, it could be interpreted that family well-being was directly influenced by the higher education of husband and wife, indirectly influenced by less economic pressure of the family, directly influenced by higher gender relations between husband and wife; and directly influenced by less or higher external support. Thus, roughly speaking, wealthy farmer families were the family that had educated husband and wife; less economic pressures; equally gender relations and partnerships; and less or more receive external supports.

\section{Discussion}

The increased number of poor people as influenced by economic crisis also means the increased incapability of families to deal with the fulfillment of their basic needs for food, clothes, education, health, and housing. This decrease in family wellbeing affects the happiness and satisfaction of their lives. The economic problems that were accompanied by the social and management problems of the family finally emerged as poverty problems for a majority of the rural areas.

In general, findings showed that farmer families in lowland areas exhibited direct influences on family well-being from gender relations between husbands and wives in family and farming activities. Gender relations were indicated by gender partnerships in decision making on family activities such as the financial expenditures on food, children education, and other expenditures, and also on farming activities, whether performed by husband/wife only, or dominantly by husband/wife, or equally between husband and wife. 
Farmer families in lowland areas exhibited more diverse and dynamic family well-being than farmer families in upland areas. The dynamics of family well-being of farmer families in lowland areas were influenced by external support that might show the degree of exchanges in goods and services among family members either intrakinships or extra kinships. The exchange of goods and services among the families influenced their social and economic conditions. However, the farmer families in upland areas seemed more independent and homogenous in family and community stability. 
Rizkillah \& Simanjuntak / Journal of Family Sciences , 2018, Vol. 03, No. 01

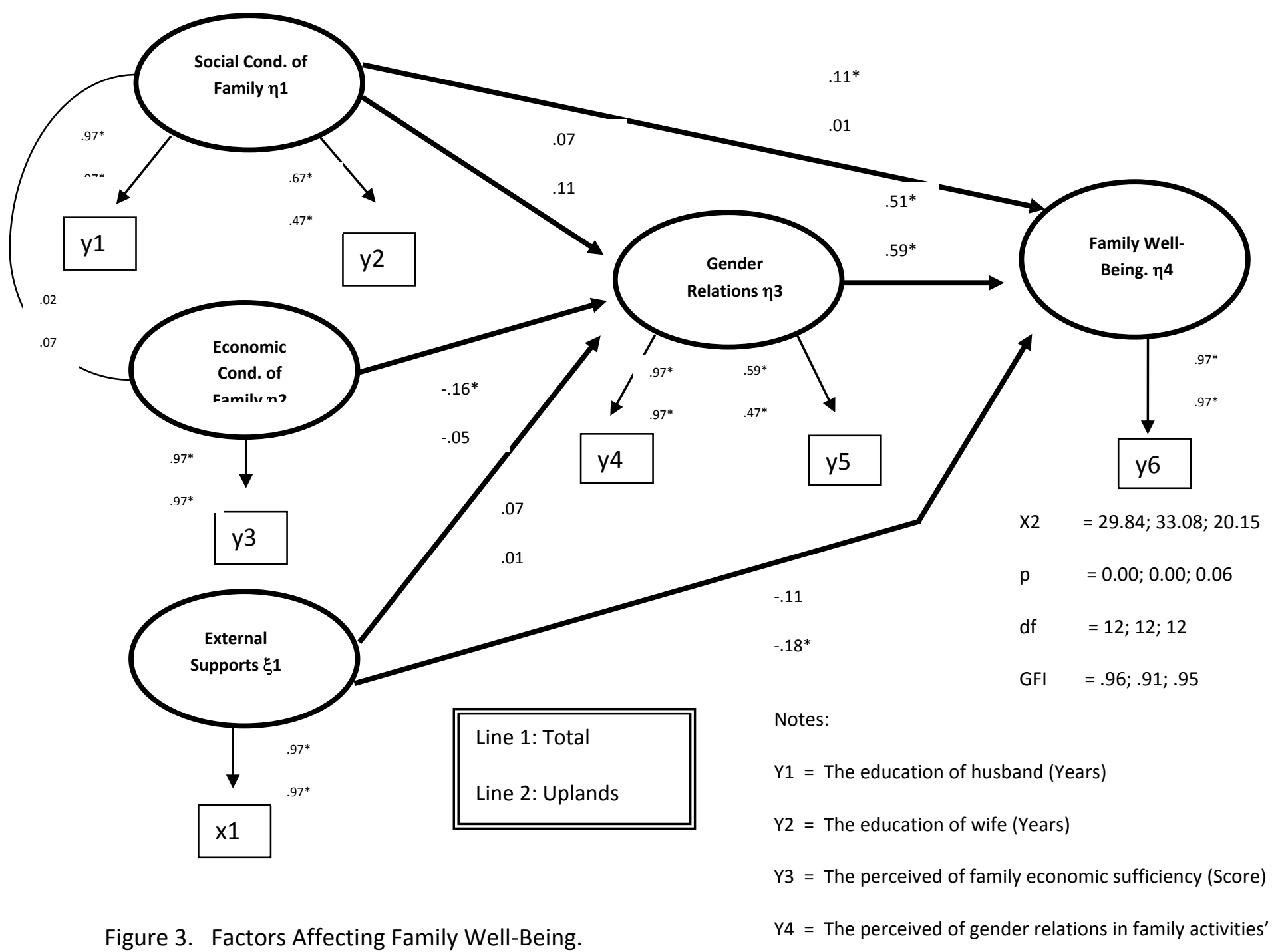


Table 3 The Decomposition Effects of Factors Influencing Subjective Family Wellbeing.

\begin{tabular}{|c|c|c|c|c|c|c|c|c|c|c|}
\hline \multirow[t]{2}{*}{ No } & \multirow[t]{2}{*}{ Variables } & \multicolumn{3}{|c|}{ Total } & \multicolumn{3}{|c|}{ Uplands } & \multicolumn{3}{|c|}{ Lowlands } \\
\hline & & TE & DE & IE & TE & DE & IE & TE & DE & IE \\
\hline \multirow[t]{4}{*}{1} & $\begin{array}{l}\text { Gender relations } \\
(\eta 3)\end{array}$ & & & & & & & & & \\
\hline & $\begin{array}{l}\text { Social cond. of } \\
\text { Family }(\eta 1)\end{array}$ & .07 & .07 & .00 & .11 & .11 & .00 & .16 & .16 & .00 \\
\hline & $\begin{array}{l}\text { Economic cond. of } \\
\text { family }(\eta 2)\end{array}$ & $-.16 *$ & $-.16 *$ & .00 & -.05 & -.05 & .00 & $-.36 *$ & $-.36 *$ & .00 \\
\hline & External supports $(\xi 1)$ & .07 & .07 & .00 & .01 & .01 & .00 & $.23 *$ & $.23 *$ & .00 \\
\hline \multirow[t]{5}{*}{2} & $\begin{array}{l}\text { Family well-being } \\
(\eta 4)\end{array}$ & & & & & & & & & \\
\hline & $\begin{array}{l}\text { Social cond. of } \\
\text { Family }(\eta 1)\end{array}$ & $.15 *$ & $.12 *$ & .03 & .07 & .01 & .06 & .14 & .08 & .06 \\
\hline & $\begin{array}{l}\text { Economic cond. of } \\
\text { family }(\eta 2)\end{array}$ & -.08 & .00 & $\begin{array}{l}- \\
.08\end{array}$ & -.03 & .00 & -.03 & $-.13 *$ & .00 & $-.13 *$ \\
\hline & External supports $(\xi 1)$ & $.51 *$ & $.51 *$ & .00 & $.59 *$ & $.59 *$ & .00 & $.37 *$ & $.37 *$ & .00 \\
\hline & Gender relations $(\eta 3)$ & -.07 & -.10 & .03 &. &. & .01 & .09 & .01 & $.08 *$ \\
\hline
\end{tabular}

$\mathrm{TE}=$ Total effect $; \mathrm{DE}=$ Direct effect $; \mathrm{IE}=$ Indirect effect

$*=\mathrm{p}<0.05$

Gender roles in decision making based on the partnership between husband and wife --as the composite of management, cutting back expenses and generating income were moderate in both upland and lowland areas. This means that the farmer families operated daily mechanisms of survival strategies to deal with poverty, even yet these were still insufficient compared to the degree of poverty problems. The education of both husband and wife were insufficient to deal with the demand for basic family needs.

The results showed that there was still hope in coping with poverty by focusing on the factors that affect family well-being. Even if farmer families in lowland areas only exhibited that gender relations and external support could influence family wellbeing, at least the theory of family management was implemented (Deacon \& Firebaugh, 1988). The basic line data is important because it shows that data on social, 
economic, and demographic attributes of the community-including kinships and local knowledge of exchanges of goods and services-should be required in local government data collection. The data on agroecosystems and agricultural potentials are also essential.

\section{Conclusions and Suggestions}

1. The largest proportion of both farmer families in upland and lowland areas had not graduated from elementary school. The average years of wives' education were 4.4 years, and the average number of family members was 6 persons. More than threefourths of farmers in both areas had average monthly incomes less than IDR 1000 000. The average monthly family income was IDR 778242.50 in upland areas and IDR 1587434 in low land areas. In general, the economic conditions of farmers in lowland areas were better than in upland areas.

2. The conditions of social-cultural and agroecosystem differ between upland and lowland areas. The conditions of upland areas of Bogor District are hilly, the potential of food crops, non-active farmer's groups -especially women's involvement, and the existence of socio-cultural constraint such as conservative norms typical of traditional agriculture communities. On the other hand, the conditions of lowland areas of Karawang District are flat, close to sea/beach, the villages are separated by very wide paddy fields, potential of rice-become a national rice stock area, active farmer's groups, low women involvement, and the norms are more moderate for changes in gender relations as typical of semi-modern agriculture communities.

3. In general, both upland and lowland areas gender roles in farming activities, within terms of access and control to agricultural resources were dominated by men. The gender relations and partnership in domestic spheres showed that in general there had been moderate partnerships between husband and wife on planning and implementing family activities in both areas. The gender partnerships between husband and wife in farming systems in upland areas were highly equal; while in lowland areas were less equal when men dominated the farming system more than women.

4. Family well-being was directly influenced by the higher education of husband and wife, indirectly influenced by less economic pressure of the family, directly influenced by higher gender relations between husband and wife; and directly influenced by less or higher external support. Thus, wealthy farmer families were the family that had educated husband and wife; less economic pressures; equally gender relations and partnerships; and less or more receive external supports.

It is recommended that the next study should add variables of family coping strategies related to family economic pressure and gender roles between husband and wife.

\section{References}

BPS-Bappenas- UNDP. 2006. Laporan Pembangunan Manusia Indonesia Tahun 2004: Ekonomi dari Demokrasi Membiayai Pembangunan Manusia Indonesia. 
Biro Pusat Statistik (BPS). 2007. Data Survei Sosial Ekonomi Nasional.

Bappenas \& ADB. 2007. Progress Report December 2007: The Pro-Poor Planning and Budgeting Project (P3B)-ADB TA 4762 INO.

Bappenas \& ADB. 2008. Progress Report January 2008: The Pro-Poor Planning and Budgeting Project (P3B)-ADB TA 4762 INO.

Chamber, R. 1995. Pembangunan Desa: MUlai dari Belakang. LP3ES. Jakarta

Conger RD, Elder GH. 1994. Families in Troubled Times: Adapting to Change in Rural America. New York: Aldine De Gruyter.

Deacon and Firebaugh. 1988. Family Resource Management Principles and Applications ( $2^{\text {nd }}$ Ed). Massachusetts: Allyn and Bacon Inc.

Gibson, R. 1993. Nutritional Assesment A Laboratory Manual. University of Guelph. Oxford University, New York.

Guhardja, S., Puspitawati,H., Hartoyo. 1992. Diktat Manajemen Sumberdaya Keluarga. Jurusan Gizi Masyarakat dan Sumberdaya Keluarga, Fakultas Pertanian, IPB. Bogor.

Joreskog, K and Sorbom, D. 2006. LISREL version 8.80 Edition Student (July 2006). Scientific Software International, Inc. Copyright 2006.

Hawadi,R.A. 2001. Psikologi Perkembangan Anak. Mengenal Sifat, Bakat dan Kemampuan Anak. Gramedia Widiasarana Indonesia. Jakarta.

Hikmat, H. 2004. Strategi Pemberdayaan Masyarakat. HUmaniora Utama. Bandung

Hurlock, E.B. 1997. Perkembangan Anak. Jilid 1. Gramedia, Jakarta

International Labour Organization (ILO). 1998. SEAPAT (South East Asia and the Pacific Multidisciplinary Advisory Team. ILO/SEAPATs On line Gender Learning \& Information Module. http://www.ilo.org/public/english/region/asro/mdtmanila/training/unit1/moserfw.h tm.

Ismael, O.J. 2005. Pengembangan Forum Kesejahteraan Sosial Berbasis Komunitas. Tesis yang Tidak Dipublikasikan. IPB, Bogor.

Kantor Menteri Negara Koordinator KEsejahteraan Rakyat. 2004. Strategi Kemiskinan Nasional. TKP3KPK. Jakarta.

Langsten, R. \& Salen, R. 2008. Two Approaches to Measuring Women's Work in Developing Countries: A Comparison of Survey Data from Egypt. Population \& Development Review; Jun2008, Vol. 34 Issue 2, p283-305, 23p, 4

Miller, C \& Razavi, S. 1998. Gender Analysis: Alternative Paradigm". UNDP website (http://www.sndp.undp.org/gender/resource/mono6.htm)

Myers, R. 1992. The Twelve Who Survive. Strengthening Programmes of Early Chilhood Development in the Third World. Routidge in Co-operation with UNESCA for the Consultative Group on Early Chilhood Care and Development, London.

Overholt, Anderson, Cloud and Austin. 1984 Gender Roles in Development Projects: A Case Book. Kumarian Press: Connecticut.

Pini, B. 2004. Counting them in, not out: Surveying Farm Women about Agricultural Leadership. Australian Geographical Studies. June 2004. 42(2):249-259.

Pini, B. 2005. Farm Women: Driving Tractors and Negotiating Gender. International Journal of Sociology of Agriculture \& Food; 2005, Vol. 13 Issue 1, p1-12, 12p.

Pranarka, W., Vidhyandika. 1996. Pemberdayaan : Konsep, Kebijakan dan Implementasi. Center for Strategic and International Studies. Jakarta. 
Pudjiadi, S. 2001. Ilmu Gizi Klinis pada Anak. Edisi keempat. Fakultas Kedokteran, Universitas Indonesia, Jakarta.

Rahardjo, D. 1995. Program-program Aksi Untuk Mengatasi Kemiskinan dan Kesejahteraan pada PJ II. Aditya Media. Yogyakarta.

Saefudin, dkk. 2003. Menuju MAsyarakat Mandiri. Pengembangan Model Sistem Keterjaminan Sosial. Gramedia Pustaka Utama. Jakarta.

Slamet, M. 2000. Paradigma baru Penyuluhan Pertanian di Era Otonomi Daerah. Tasikmalaya. Jawa BArat : Seminar PERHIPTANI.

Slamet, M. 2000. Pemberdayaan Sumberdaya Manusia Menuju Terwujudnya Masyarakat Madani (Proseding Seminar Nasional. Kerjasama PAPPI dengan Program Studi Penyuluhan Pembangunan. PPS-IPB Bogor. Pustaka Wirausaha Muda.

Satoto. 1997. Fitrah dan Tumbuh-Kembang Anak. Pidato Pengukuhan Jabatan Guru Besar Tetap dalam Ilmu Gizi pada Fakultas Kedokteran Universitas Diponegoro. Semarang.

Satoto. 1990. Pertumbuhan dan Perkembangan Anak. Pengamatan 0-18 bulan di Kecamatan Mlonggo, Kabupaten Jepara, Jawa Tengah. Disertasi untuk Memperoleh Gelar Doktor dalam Ilmu Kesehatan, UNDIP, Semarang.

Soemarjan, S. 1998. Dampak Berbagai Krisis Rumah Tangga. LIPI. Jakarta.

Sumidiningrat, G. 1999. Pemberdayaan Masyarakat dan JPS. Gramedia Pustaka Utama. Jakarata.

Toronto-Ontario Social Development Council, 1997

Trikoesoemaningtyas, Puspitawati, H., Herawati, T. 2006. Peran Gender Dalam Usaha Tani. Laporan Penelitian Kerjasama Departemen Agronomi dan Hortikultura, ICRAF dan USAID. Bogor,

USAID. 2006. Integrating gender into Reproductive Health and HIV Programs. Extending Service Delivery Project: Best Practice Tools Series \#2.

Vaydanoff. (1988). Economic Distress, Family Copying and Quality of Family Life. Newbury, CA. Sage.

Wijaya, K., Budidarso, S., Rosbetko, J. 2006. Socio Economic Studies Agroforestry and Sustainable Vegetable Production in Southeast Asian Watershed. Research Report ICRAF-USAID. Bogor.

WHO. 1995. Physical Status: The Use and Interpretation of Antrophomentry. Report of a WHO Expert Committee. WHO Technical Report Series 854. WHO, Geneva.

WHO. 2000. Complementary feeding of young children in developing countries. A review of current scientific knowledge. 